\title{
The Variability of Indonesian Throughflow in Sumba Strait and Its Linkage to the Climate Events
}

\author{
${ }^{1}$ Ahmad Bayhaqi, ${ }^{2}$ Yueng-Djern Lenn, ${ }^{1}$ Dewi Surinati, ${ }^{3}$ Jeff Polton, ${ }^{4}$ Muhamad Nur, \\ ${ }^{1}$ Corry Corvianawatie and ${ }^{1}$ Adi Purwandana \\ ${ }^{1}$ Research Center for Oceanography, Indonesian Institute of Sciences, Jakarta, Indonesia \\ ${ }^{2}$ School of Ocean Sciences, Bangor University, Wales, United Kingdom \\ ${ }^{3}$ National Oceanography Centre, Liverpool, United Kingdom \\ ${ }^{4}$ Graduate School of Physics, Natural Science, University of Sriwijaya, Palembang, Indonesia
}

Article history

Received: $17-12-2018$

Revised: 22-05-2019

Accepted: 30-05-2019

Corresponding Author:

Ahmad Bayhaqi

Research Center for

Oceanography, Indonesian

Institute of Sciences, Jakarta,

Indonesia

Email: <ahmad.bayhaqi@lipi.go.id>

\begin{abstract}
As one of the Indonesian Throughflow (ITF) outflow passages, the Sumba Strait is a meeting point for the Pacific and the Indian Ocean water mass. In order to study the long-term variability of ITF flowing via Sumba Strait, this research uses observational data from the Ekspedisi WIdya Nusantara (EWIN) research cruise conducted in August 2016 to validate the altimetric geostrophic surface current by referencing the shear velocity. Stating the referenced level to $700 \mathrm{~m}$, geostrophic transport is calculated using the Monthly Isopycnal/Mixed-Layer Ocean Climatology (MIMOC) data. Over the period of 1993-2016, the results demonstrate a dominant seasonal pattern for the geostrophic variability. While the total geostrophic transport shows a main westward direction towards the Indian Ocean, the Sumba Strait provides only a small portion (less than $0.1 \mathrm{~Sv}$ ) for westward ITF geostrophic current. Intraseasonally, the maximum transport occurs during the southeast monsoon. The reversal of South Java Current (SJC), which flows with the eastward direction heading to the Savu Sea, is observed as the intrusion for westward ITF in almost every monsoon season. Despite having an unclear year to year cycle, climate mode of the Indian Ocean may have more influence on the surface geostrophic variability at the Sumba Strait. On the other hand, ocean-atmosphere coupling in the Pacific Ocean has a role in regulating geostrophic transport variation within the Sumba Strait. Using a statistical approach, the findings emphasize that the throughflow may well be impacted as well as feedback on both ENSO and IOD since there is robustness in those variables.
\end{abstract}

Keywords: Geostrophic Current, Indonesian Throughflow, Sumba Strait, El Nino, La Nina

\section{Introduction}

It has been well-known that Indonesian seas are the only pathway for the Pacific and Indian Ocean interconnection in the equatorial zone (Broecker, 1997; Koch-Larrouy et al., 2007; Sprintall and Revelard, 2014). These flows, which has been named as the Indonesian Throughflow (ITF) (Wyrtki, 1987), bring the Pacific warm water into the Indian Ocean through the internal Indonesian Seas (Wijffels et al., 1992; Ganachaud et al., 2000) giving the influence for global ocean thermohaline, heat budget (Gordon, 1986) and being a significant part in Australasian regional climate (Hautala et al., 2001). Based on the model simulation, as part of global overturning circulation in the surface layer (Feng et al., 2018), the ITF and regional convection process can change the global atmospheric circulation and the pattern of mid-latitude winds by moving the sea surface temperature from Pacific into the Indian Ocean (Schneider, 1988). Hence, the ITF plays a crucial role in both the ocean and atmosphere.

Many aspects of ITF have been examined using many ways such as the field measurement (research cruise) including geostrophic analysis (Meyers et al., 1995; Gordon et al., 2010; Susanto et al., 2012), model simulation as well as satellite data utilization (Susanto and Song, 2015) to figure out its transport (Wyrtki, 1961; Gordon, 1986; Sprintall et al., 2009), heat transport and flux (Godfrey, 1996; Vranes et al., 2002) also its variability and response to the climate event (England and Huang, 2005; Sprintall 
and Revelard, 2004). Previous studies have focused on the throughflow flowing through the major inflow (Makassar Strait) (England and Huang, 2005; Gordon et al., 2008; Susanto et al., 2012; Fan et al., 2018) while the variability of ITF have been studied by Hautala et al. (2001) and Atmadipoera et al. (2009). However, the information on ITF variability within the Sumba Strait is less than the other outflow passages (Hautala et al., 2001).

Based on the geographical location, the Indonesian seas are not only involved by the influence of the Pacific Ocean but also from the Indian Ocean. The contribution of Indian Ocean comes from an eastward equatorial jet (Wyrtki, 1973) transmitting the coastal Kelvin Wave (Clarke and Liu, 1993) and eastward South Java Current (SJC) (Quadfasel and Creswell, 1992). In some occasions, these Indian Ocean flows act as the intrusion for ITF transport in internal Indonesian Seas. For example, semiannual Kelvin Wave in May and November which propagates through Lombok Strait (Sprintall et al., 1999; Sprintall et al., 2000; Syamsudin et al., 2004; Shinoda et al., 2012) can reduce the southward Makassar flow below 200 meter (Arief and Murray, 1996). Furthermore, the Kelvin Wave which moves as the SJC and South Java Under Current (SJUC) flows into the Ombai Strait via Sumba Strait and Savu Sea (Sprintall et al., 2010). These currents potentially reduce the flow transport from the branch of Makassar flow which moves into the Indian Ocean through Banda Sea (Sprintall et al., 2003) and outflow passages such as Ombai Strait and Timor Passage. Interestingly, the research cruise of Ekspedisi Widya Nusantara (EWIN) in 2016 which was conducted by Indonesian Institute of Science (LIPI) found the evidence of minor ITF flow which also moves to the Indian Ocean via Sumba Strait and gets the distraction from the eastward SJC (Bayhaqi et al., 2018). The snapshot finding from EWIN encourages this study to figure out the long term variability of South Java Current and ITF component which flows via Sumba Strait.

To enhance the understanding of the ITF variability flowing via Sumba Strait, this paper attempts to fill the gap from the previous studies. The longtime series data from an altimetry satellite, which were collected over a period of 24 years (from 1993 to 2016), are used to determine the flow variability by examining the surface geostrophic current. A validation for satellite data involves the shear referencing between geostrophic inferred hydrography data and measured ocean current. The variability is then analysed on the annual and interannual cycle. Also, with the same time scale, the sea surface temperature anomaly data are managed to figure out the climate events over the period of this study. A will be revealed, these results help to define the throughflow variability, focused on Sumba Strait. Moreover, its response to climate modes is also evaluated.

\section{Methodology}

\section{The Source of Data}

In this study, the primary data comes from the Ekspedisi Widya Nusantara (EWIN 2016) annual research cruise, which was conducted by Research Center for Oceanography- Indonesian Institute of Sciences (LIPI) using Research Vessel (R/V) Baruna Jaya VIII. These observation data contain hydrographic data and ocean current profile which are recorded by Conductivity Temperature Depth (CTD) SBE 911 plus manufactured 2014 and Shipboard Acoustic Doppler Current Profiler (SADCP) $75 \mathrm{kHz}$ RDI instrument (BBVMADCP) respectively.

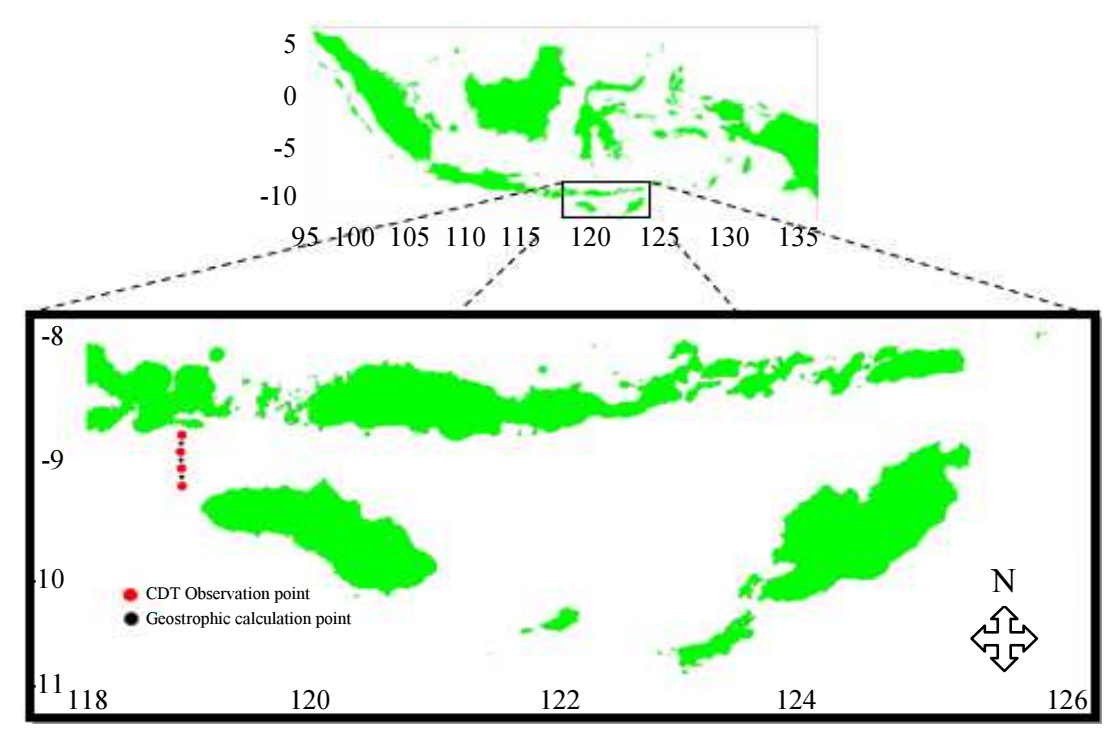

Fig. 1: Map showing the Indonesian region (top) and the position of hydrographic station in Sumba strait (bottom). 
The CTD instrument measured the hydrographic data including temperature, salinity and pressure in four stations from the surface to the bottom of water column, which depended on the maximum depth of each station. Thus, due to the different bathymetry, the maximum measurement in station one (1) was only until $700 \mathrm{~m}$ while the others were $1000 \mathrm{~m}$. The stations for measuring the hydrography data can be seen in Fig. 1 (the northest red dot refers to the station 1 while the southest one is station 4). On the other hand, the RDI ADCP recorded the ocean current data along the cruise track. The ADCP has the ability to record data until 128 bin with $8 \mathrm{~m}$ for the blank zone after transmitting and 5 $\mathrm{m}$ bin interval (total depth measurement $=648 \mathrm{~m}$ ).

Besides the observation, this study also uses the secondary data from satellite such as surface geostrophic velocity, which were obtained from AVISO with the resolution $0.25^{\circ} \times 0.25^{\circ}$, and monthly sea surface temperature (SST) from the NOAA Optimum Interpolation (OI). Furthermore, Monthly Isopycnal/Mixed-Layer Ocean Climatology (MIMOC) data is employed to determine the geostrophic transport.

\section{Data Processing}

Surface Geostrophic Velocity and Shear Referencing

In the mathematical equation, Stewart (2002) described the formula of geostrophic velocity which can be written as:

$$
\frac{\partial p}{\partial x}=\rho f v
$$

$\frac{\partial p}{\partial y}=-\rho f u$

$$
\frac{\partial p}{\partial z}=-\rho g
$$

where the notation of $f$ defines the Coriolis force with the function $f=2 \Omega \sin \varphi$ which relies on the latitude position $(\varphi)$. Based on Pond and Pickard (1978), from those equations, the velocity of geostrophic current can be obtained by:

$$
v=\frac{1}{f \rho} \frac{\partial p}{\partial x} ; u=-\frac{1}{f \rho} \frac{\partial p}{\partial y}
$$

and the pressure can be written as:

$$
P=P_{0}+\int_{-h}^{\eta} g(\varnothing, z) \rho(z) \partial z
$$

where, $P_{0}=$ atmospheric pressure; $\int_{-h}^{\eta} g \rho \partial z=$ water pressure below the surface and $\eta=$ surface elevation.
According to Stewart (2002), from substitution the Equation (5) into (4), we can get:

$$
\begin{aligned}
& u=-\frac{1}{f \rho} \frac{\partial}{\partial y} \int_{-h}^{0} g \rho \partial z-\frac{1}{f \rho} \frac{\partial}{\partial y} \int_{0}^{\eta} g \rho \partial z \\
& u=-\frac{1}{f \rho} \frac{\partial}{\partial y} \int_{-h}^{0} g \rho \partial z-\frac{1}{f \rho} \frac{(\rho g \eta)}{\partial y} \\
& u=-\frac{1}{f \rho} \frac{\partial}{\partial y} \int_{-h}^{0} g \rho \partial z-\frac{g}{f} \frac{\partial \eta}{\partial y}
\end{aligned}
$$

where $\frac{g}{f} \frac{\partial \eta}{\partial y}$ is the pressure gradient in the surface which produces the surface velocity in xy-direction, then:

$u=-\frac{1}{f \rho} \frac{\partial}{\partial y} \int_{-h}^{0} g \rho \partial z-u_{s}$

with the same method:

$$
\begin{aligned}
& v=\frac{1}{f \rho} \frac{\partial}{\partial x} \int_{-h}^{0} g \rho \partial z+\frac{g}{f} \frac{\partial \eta}{\partial x} \\
& v=\frac{1}{f \rho} \frac{\partial}{\partial x} \int_{-h}^{0} g \rho \partial z+v_{s}
\end{aligned}
$$

the first term on the right-hand side of Equation (7) and (8) is the pressure gradient in the xy-direction.

Related to the geostrophic measurement from the observation, Pond and Pickard (1983) defining the formula to calculate the geostrophic current between two hydrographic stations, then the formula can be written as:

$\left(V_{2}-V_{1}\right)=\frac{10\left[\Delta D_{2}-\Delta D_{2}\right]}{2 L \Omega \sin \varphi}$

where, $\left(V_{2}-V_{1}\right)$ is the velocity of geostrophic between two stations with the unit $\mathrm{m} / \mathrm{s}, \Delta D_{1}$ and $\Delta D_{1}$ is the dynamic height between two stations with the unit (dyn.m), $L$ is the distance between two stations with the unit meter, $\Omega$ is the angular velocity of the Earth's rotation which can be defined by $\left(7.292 \times 10^{-5} \mathrm{rad} / \mathrm{sec}\right)$ and $\varphi$ is the latitude position of two stations (in the center) in degree. Basically, to calculate the geostrophic, it requires the specific velocity value in the surface (Us and Vs) or below to get the absolute velocity (Stewart, 2002). It takes the referenced value from the lower layer where it can be assumed as very small velocty or zero. That level can be called as level no motion or level no friction (Talley et al., 2011). There are several depths which are used by scientists to determine the geostrophic velocity such as $450 \mathrm{~m}$ (Kessler, 2006), $500 \mathrm{~m}$ (Strub and James, 2002), $700 \mathrm{~m}$ (Liu et al., 2015) and $1000 \mathrm{~m}$ (Lavin et al., 2006). Considering the depth of CTD data from the field measurement, the referenced depth in this study is $1000 \mathrm{~m}$. 
After getting the geostrophic velocity from the observation data, the shear measurement is calculated using $\frac{\partial u}{\partial z}$ for both geostrophic velocities inferred from hydrography data and direct measured current from ADCP. This method is performed because the magnitudes of geostrophic and direct measured current are difficult to be compared due to the different method. Then, the shear referencing is employed to get the best fit velocity based on referenced depth with the formula as follow:

$$
\Delta_{v}=U_{g(z 1)}-U_{A D C P(z 1)} U g=U_{g(z)}-\Delta_{v}
$$

where $\Delta_{v}$ is the difference velocity between the geostrophic velocity and ADCP in the depth where shear ADCP has the same value with shear geostrophic.

\section{Geostrophic Transport Calculation}

Consisting the value of temperature and salinity from the surface to the bottom depth, MIMOC data with the resolution $0.5^{\circ} \times 0.5^{\circ}$ are used to determine the geostrophic transport. However, since its resolution is larger than the study area (Sumba Strait), the interpolation process is conducted to get the fit position of station pair with the study location. Considering the maximum depth of station pair, the referenced level of $700 \mathrm{~m}$ is used for geostrophic transport calculation.

\section{Climate Mode Index}

Monthly Sea Surface Temperature (SST) data from the National Oceanic and Atmospheric Administration (NOAA) Optimum Interpolation (OI) SST with the resolution of $0.25^{\circ}$ are used to identify the climate mode

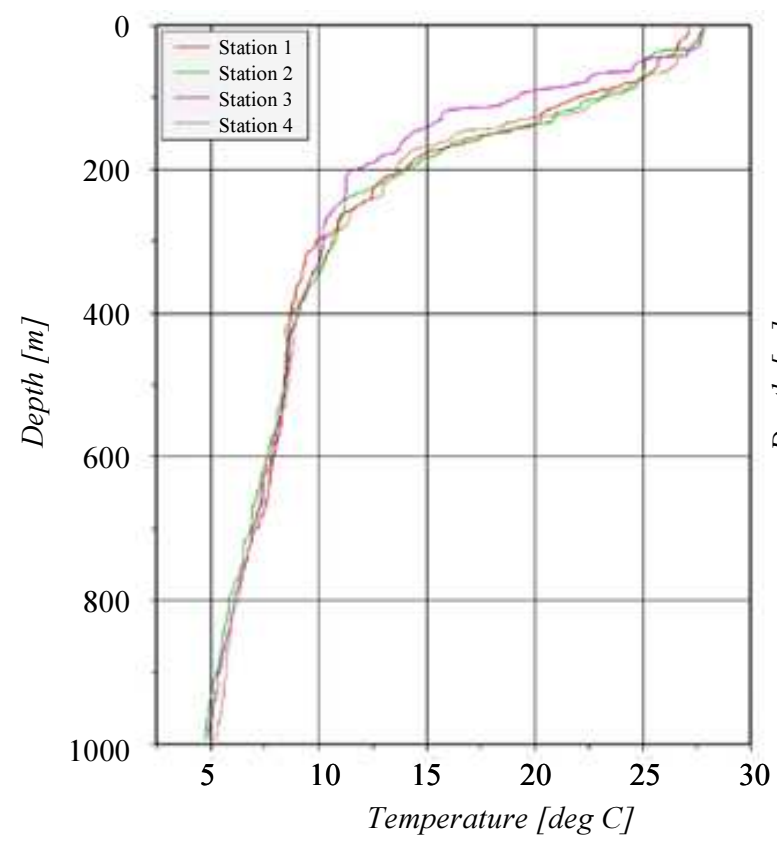

events during the periods using the Sea Surface Temperature (SST) anomaly. The term of STT anomaly in this study is the deviation from the mean climatology. The climatology then comes from the time series data over the given period. The SST anomaly in the Equatorial Pacific Ocean over the box $120^{\circ} \mathrm{W}-170^{\circ} \mathrm{W}$, $5^{\circ} \mathrm{S}-5^{\circ} \mathrm{N}$ is stated as the NINO 3.4 index is used to identify ENSO variations (Trenberth et al., 2002). On the other hand, the east-west temperature gradient between Western and Southeastern Equatorial Indian Ocean is interpreted as Dipole Mode Index (DMI) which will be utilized to investigate the Indian Ocean Dipole (IOD) mode (Saji et al., 1999).

\section{Results}

\section{Salinity and Temperature Profile}

Figure 2 showed the vertical profile of temperature and salinity as well as the T-S diagram in the Sumba Strait from the CTD instrument. Generally, the range of temperature for all stations is from $4{ }^{\circ} \mathrm{C}$ until $27^{\circ} \mathrm{C}$ while the salinity value varies from the 34-34.6\%. Based on the T-S diagram, temperature and salinity profile indicate the two water masses within Sumba Strait. The water mass with the maximum salinity 34.5 psu and temperature $22^{\circ} \mathrm{C}$ which is found in the isopycnal $\sigma \theta=23-24 \mathrm{~kg} / \mathrm{m}^{3}$ characterizes the Northern Pacific Subtropical Water (NPSW). Furthermore, the maximum salinity $34.7 \mathrm{psu}$ and temperature $8^{\circ} \mathrm{C}$ which are observed in the isopycnal $\sigma \theta=26-27 \mathrm{~kg} / \mathrm{m}^{3}$ specify the Northern Indian Intermediate Water (NIIW). Hence, the profile illustrated that the Indian Ocean and Pacific water masses penetrate the upper layer (0-600 m) of Sumba Strait.

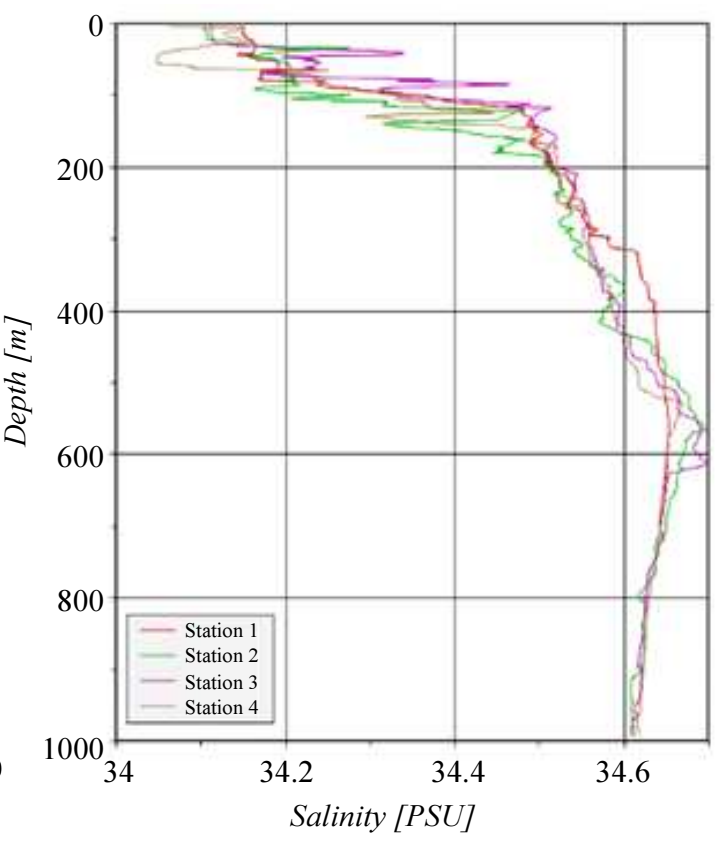




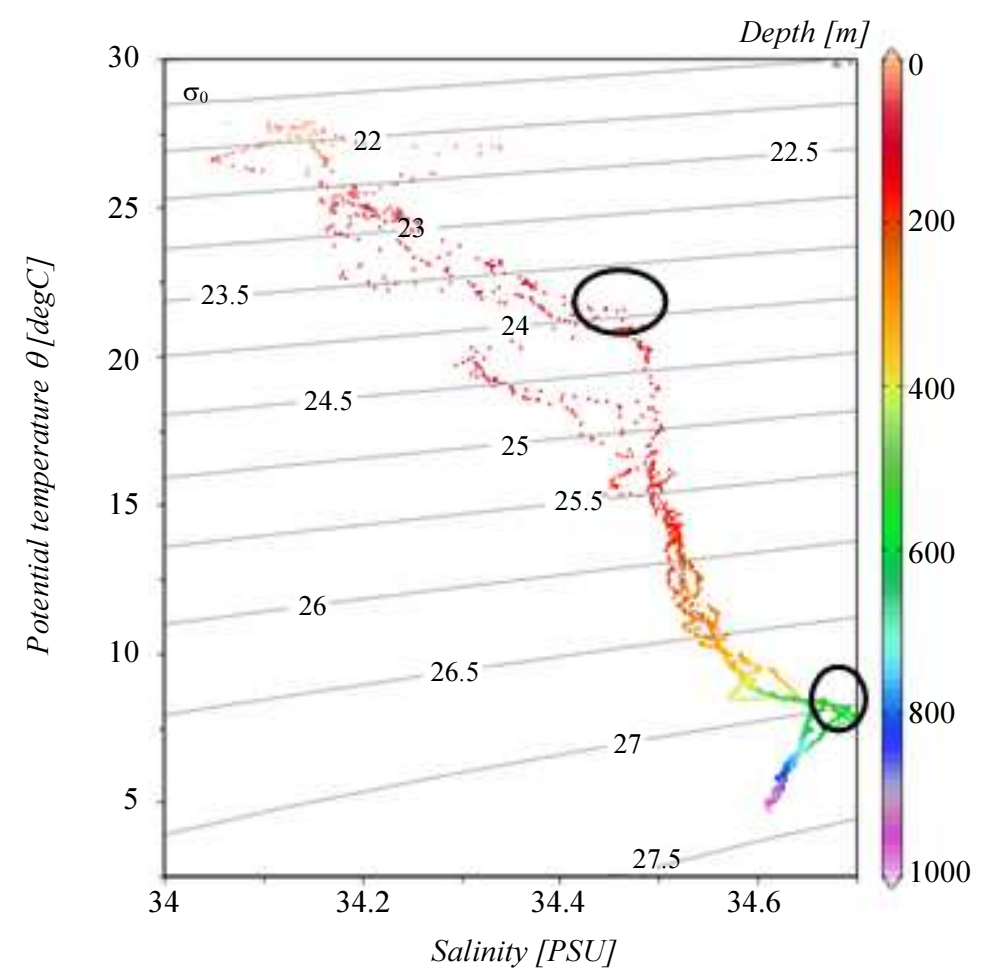

Fig. 2: Vertical profile of temperature (A) and salinity (B) for all hydrographic stations in Sumba strait

\section{Snapshot Geostrophic Velocity and Transport}

The geostrophic velocity from the hydrography data in Sumba strait (Fig 3A) is in the range between -0.83 and $0.34 \mathrm{~m} / \mathrm{s}$ with the domination of westward flow in the hydrographic pair station 1-2 and 3-4. On the other hand, there is an eastward current in the upper layer for the pair station 2-3 while in the lower layer has the same pattern with the rest pair stations. This result illustrates the potential extended propagation of South Java Current through the middle of Sumba Strait which intrudes the ITF pathways in the upper layer to be two branches. The westward geostrophic ITF is much stronger in the upper part (toward the Sumbawa Islands) of the strait than the lower part. Related to the snapshot transport velocity (Fig. 3B) during the field measurement, the geostrophic flow moves with the maximum westward $0.013 \mathrm{~Sv}$ and $0.005 \mathrm{~Sv}$ as the maximum eastward. As the comparison, this value is much smaller than the average total transport of ITF in the opposite strait, Ombai with the $4.9 \mathrm{~Sv}$ to the west (Sprintall et al., 2009). This condition is already expected since there is only a small portion of ITF turning to the Sumba Strait while the majority of them flows through the Savu/Dao Strait before exiting to the Indian Ocean. To give a better llustration, the dynamic height chart including the flow direction is provided in Fig. 4.

\section{Shear Comparison}

Since there is a different method between measuredcurrent ADCP and geostrophic current from the hydrographic station, shear referencing is conducted to figure out the true surface geostrophic velocity through examining the depth where geostrophic current dominates the total measured current from ADCP. Table 1 showed similar values between the two shear calculations. Those values vary in the depth for each station. Overall, the ADCP records the signal of geostrophic in depth over $200 \mathrm{~m}$. However, only the pair station 1-2 has the similar shear in the depth below $100 \mathrm{~m}$. This condition occurs due to bathymetry variation which leads to the difference in maximum depth measurement in the field. The subtraction of geostrophic and ADCP velocity in the defined depth $(\Delta \mathrm{u})$ where has the similar shear will be used to calculate the true surface geostrophic velocity by subtracting the calculatedgeostrophic from hydrographic station to the $\Delta \mathrm{u}$. The shear comparison between shear ADCP and geostrophic is presented for all depth can be seen in Fig. 5 .

Then, the true surface velocity of geostrophic current is employed to be verification value for surface geostrophic from altimetry satellite. Plotting the comparison between hydrographic surface geostrophic velocity and satellite data (Fig. 6), there is a positive correlation with the determination $\mathrm{R}^{2}=0.8317$. This result showed that the altimetric surface geostrophic current is good in confident level to be used for constructing the long time series of ITF variability. 


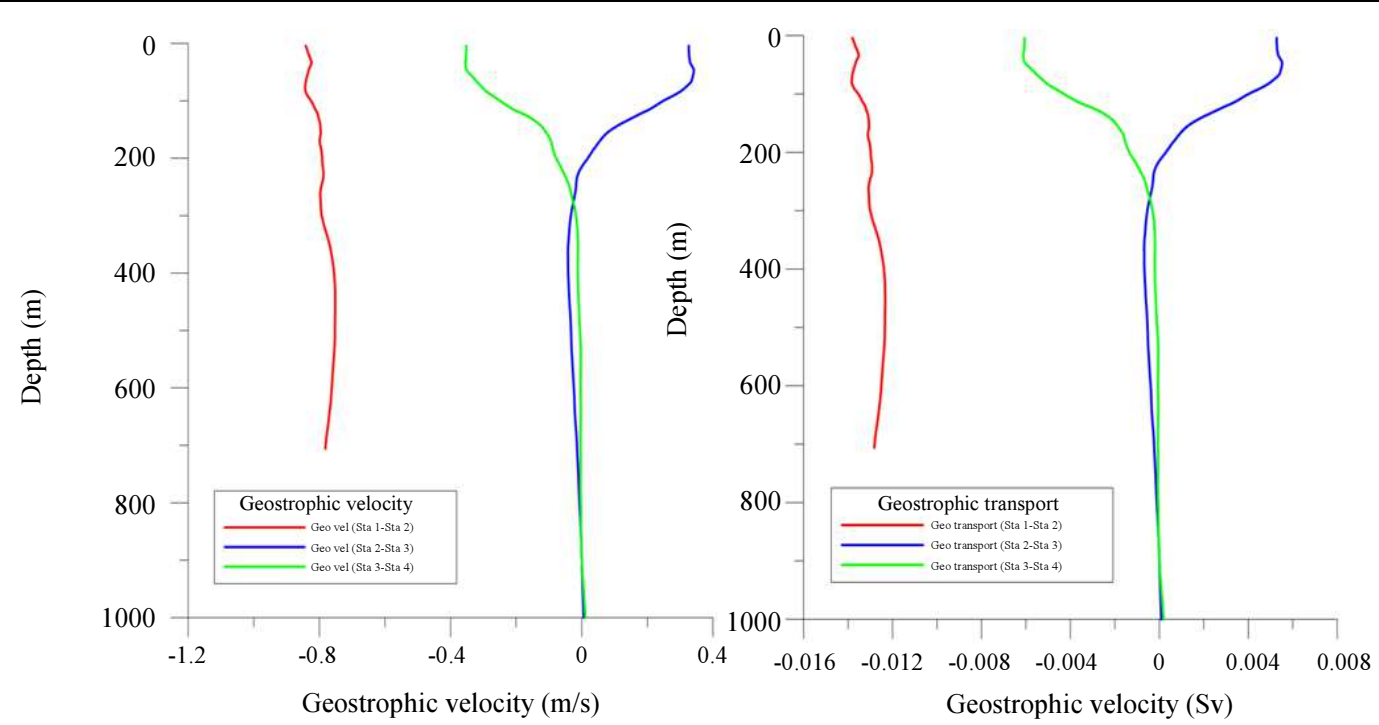

(a)

(b)

Fig. 3: Vertical profile of geostrophic velocity (a) and transport (b). Minus sign (-) means the westward current and plus (+) sign defines the eastward flow

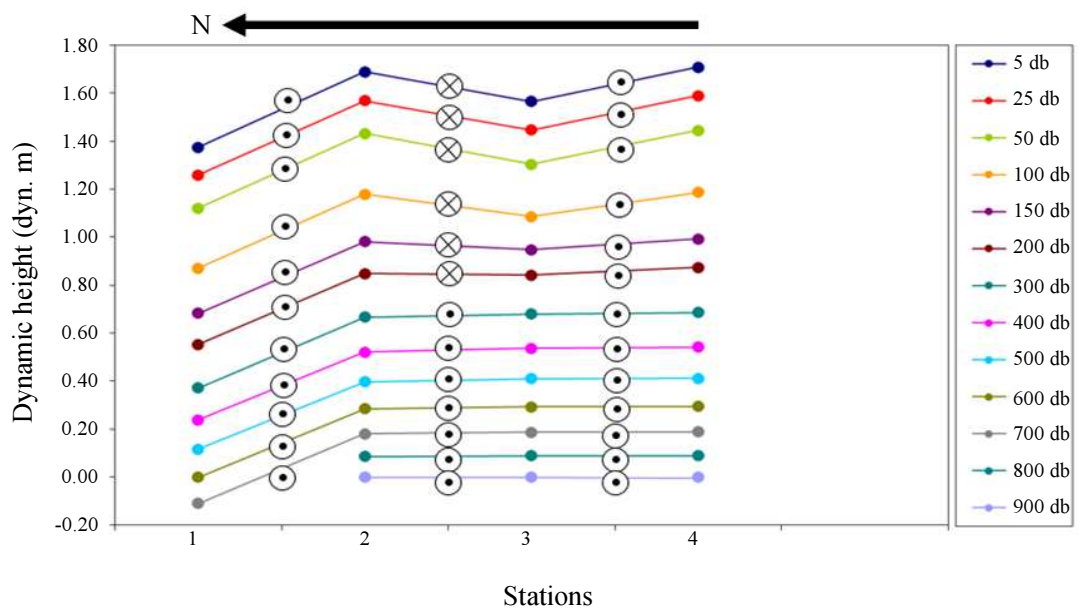

Fig. 4: Vertical Profile of dynamic height which is calculated from density distribution in all stations. The direction of flow in Sumba Strait is showed from the symbol (outward through the paper or westward) and (inward through the paper (eastward)

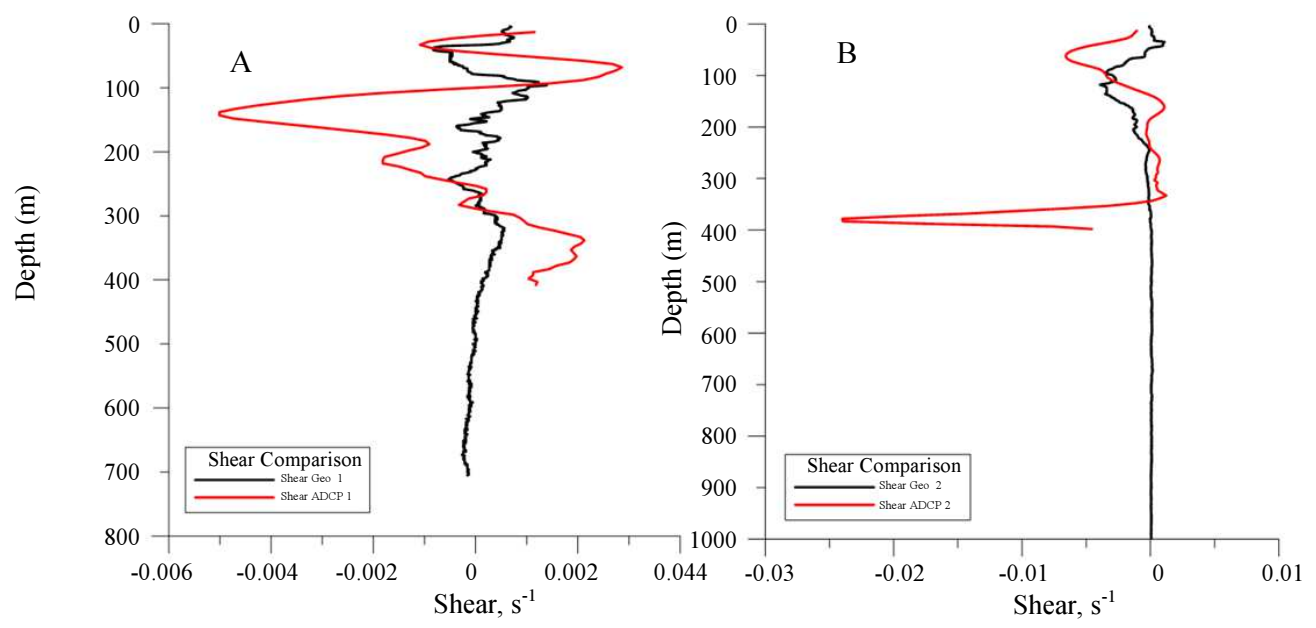




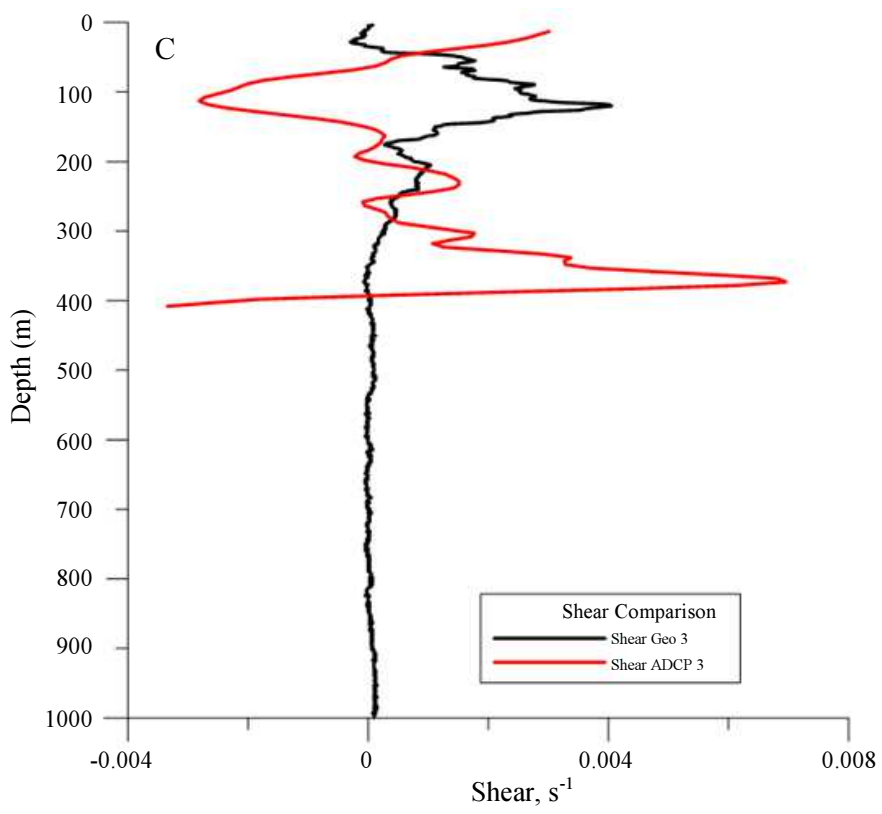

Fig. 5: Shear comparison between geostrophic inferred from hydrographic stations and ADCP measured current in full depth profile. (A) Pair Station 1-2, (B) Pair Station 2-3, (C) Pair Station 3-4

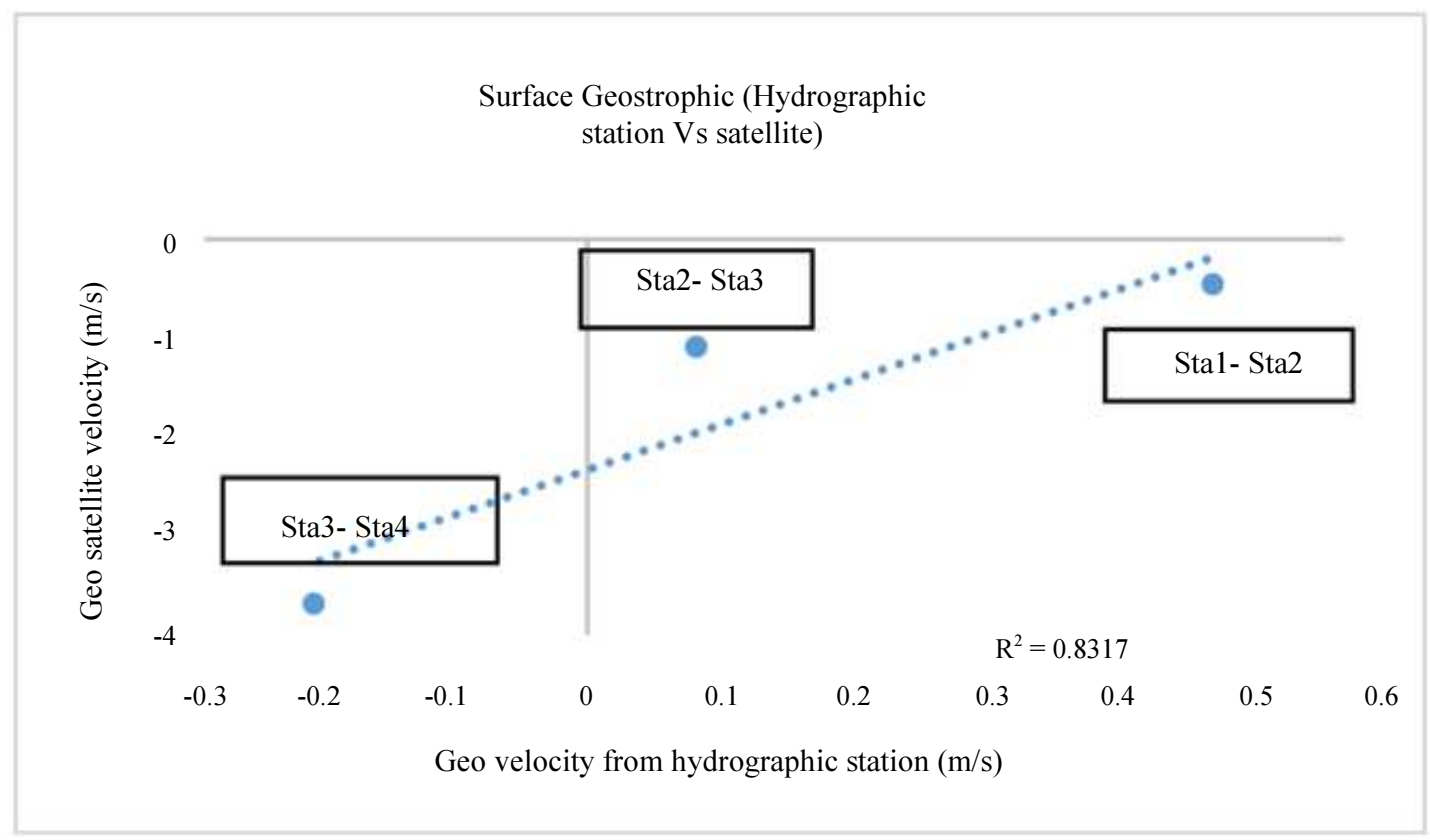

Fig. 6: Relationship plot between surface geostrophic from hydrographic station and satellite. The geostrophic velocity (x-axis) is relative to $1000 \mathrm{~m}$

Table 1: Shear comparison between geostrophic inferred from hydrographic stations and measured current ADCP in the certain depth where has a similar value

\begin{tabular}{llll}
\hline & & Shear, $\mathrm{s}^{-1}$ & \\
Pair station & Depth $(\mathrm{m})$ & ADCP & Geostrophic \\
\hline Sta 1 - Sta 2 & 53 & -0.0005 & -0.0005 \\
Sta 2 - Sta 3 & 248 & -0.0001 & -0.0001 \\
Sta 3 - Sta 4 & 283 & 0.0004 & 0.0004 \\
\hline
\end{tabular}




\section{Geostrophic Variability}

\section{Intraseasonal}

To achieve a better understanding of the geostrophic variability in Sumba strait, here the satellite data were used to determine the variation of surface geostrophic current flowing in Sumba strait. The result from the monthly average of surface geostrophic velocity during 1993-2016 from the satellite data showed the trend of inter-seasonal variability (Fig. 7). Generally, the variability of surface geostrophic in the northern part of the Strait is dominated by the eastward current while the westward flow is observed in the southern part in all seasons. Based on the result, there is a north-westward current in all stations during the northwest monsoon (DJF) with the strongest velocity $0.37 \mathrm{~m} / \mathrm{s}$ in the southern part of the strait. This westward flow is suggested as the part of ITF water mass since the contribution of southward Pacific water mass brings the warm and less saline water and moves to the Indian Ocean through the Halmahera Sea.

The reversal flows are observed in the first transitional monsoon period (MAM, northwest to southeast monsoon). In March, there is an eastward flow in the upper part of the strait and getting stronger until May with the magnitude $0.4 \mathrm{~m} / \mathrm{s}$. In addition, the northwest current in the middle of the strait (Station 2) recirculates to the northeast in April and turns to the east a month later with the magnitude $0.1 \mathrm{~m} / \mathrm{s}$ (lower than the upper part). This eastward current is assumed as the input from the South Java Current (SJC). As the opposite condition, the westward flow of ITF gets weaker in this period.

The eastward SJC gradually strengthened from 0.4 $\mathrm{m} / \mathrm{s}$ and reached the peak with the velocity $0.65 \mathrm{~m} / \mathrm{s}$ in
August of southeast monsoon (JJA). During this monsoon period, a clear pattern of eastward SJC was found in the two sections of the strait (geostrophic station 1 and 2). Due to the strong intensity of eastward SJC, this condition remains the small portion in the southern part of the strait for the ITF. The westward ITF moves to the Indian Ocean progressively with the lower magnitude. Although the ITF has strong transport during this monsoon period, this result reveals that Sumba strait does not act as the major outflow since the majority transport of ITF move through Ombai strait, Dao/Savu Strait and Timor Passage. During the second transitional monsoon period (SON, southeast to northwest monsoon), there is no significant change in current direction from the previous monsoon period. However, the eastward current speed started to decrease consistently from $0.5 \mathrm{~m} / \mathrm{s}$ to $0.27 \mathrm{~m} / \mathrm{s}$ while the magnitude of westward ITF increases from $0.25 \mathrm{~m} / \mathrm{s}$ to $0.28 \mathrm{~m} / \mathrm{s}$ in September-October period.

Measuring the total transport which flows within Sumba Strait in $700 \mathrm{~m}$ from the monthly climatology of hydrography (MIMOC) data resulted in the dominant westward current (Fig. 8). This flow is expected as the part of ITF propagation to the Indian Ocean. Different from the current at the surface layer, the variation of geostrophic transport showed that the maximum transport occurs during the Southeast Monsoon (SEM) with the range between $-0.06 \mathrm{~Sv}$ until $-0.09 \mathrm{~Sv}$. The geostrophic flows remain strong until the second transitional period and decrease in the last month (November). Then, the minimum transport exists in the Northwest Monsoon (NWM) with the range between $0.006 \mathrm{~Sv}$ until $-0.02 \mathrm{~Sv}$. The minus (-) sign in the transport value defines the direction to the west.

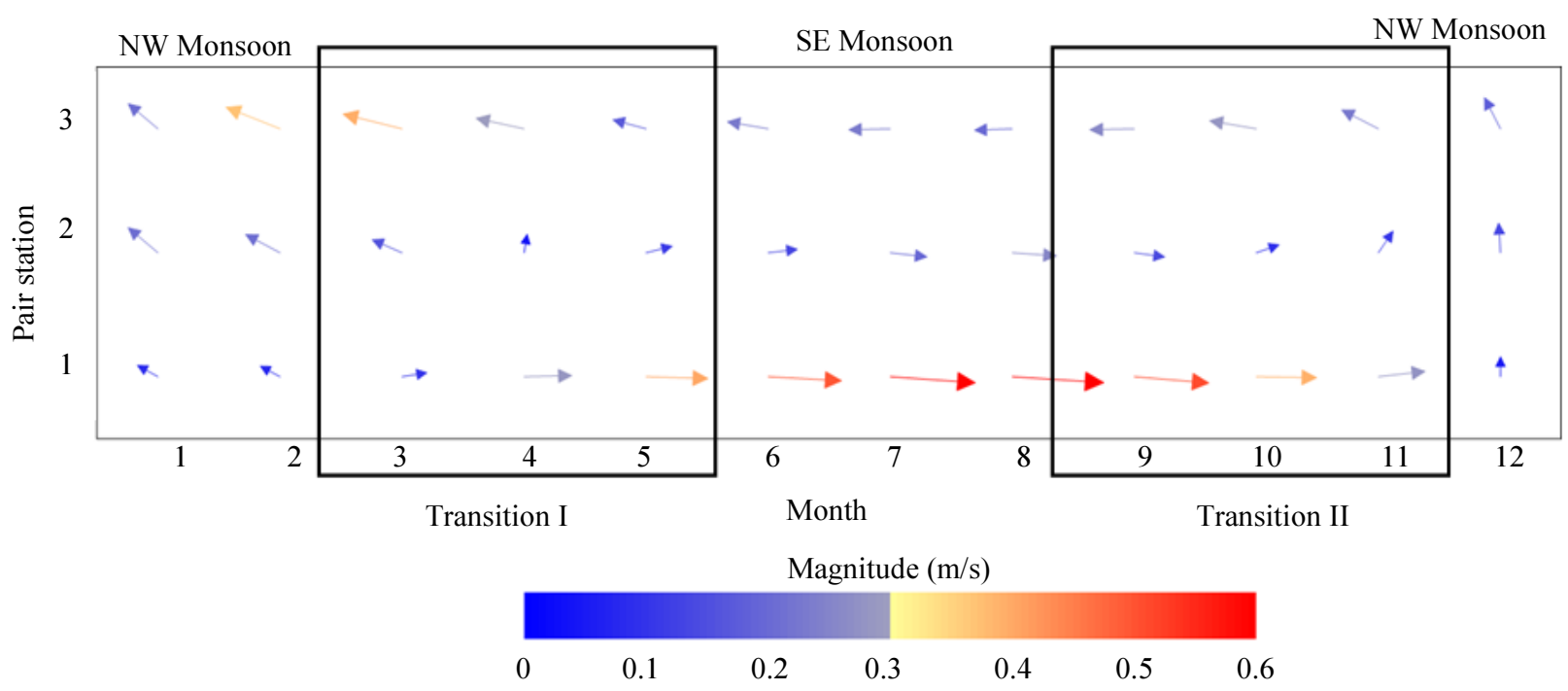

Fig. 7: Seasonal Variability of surface geostrophic in the Sumba Strait during 1993-2016. Pair station 1 (CTD Station 1-2), Pair Station 2 (CTD Station 2-3), Pair Station 3(CTD Station 3-4) 


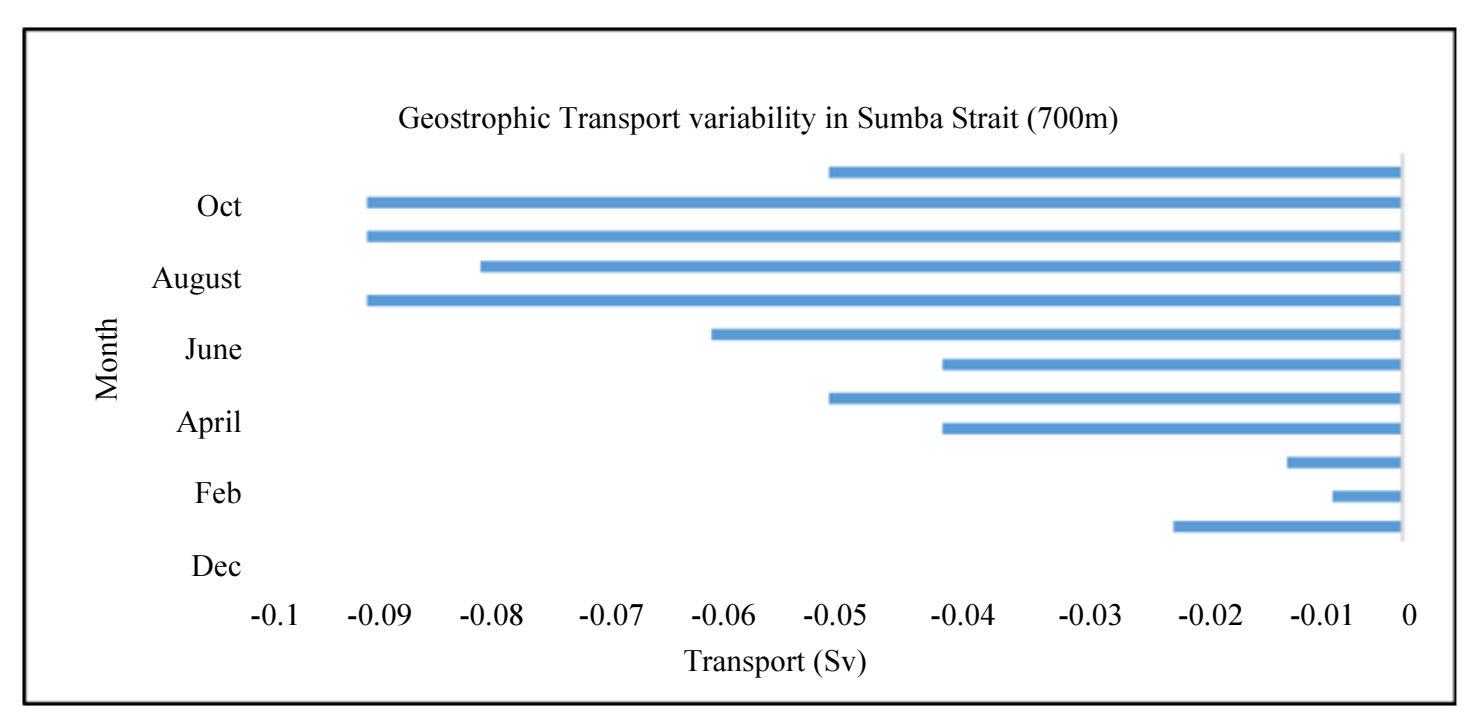

Fig. 8: Seasonal Variability of Geostrophic Transport in Sumba Strait. (NWM: Northwest Monsoon; SEM:Southeast Monsoon)

\section{Interannual}

The ocean-atmosphere modes happened repetitively from January 1993 until December 2016. Figure 9 illustrates the existence of El Niño/La Niña and Positive/Negative IOD based on the NINO 3.4 index and Dipole Mode Index (DMI) where the blue and red color indicate the presence of its event. Based on the result, 8 El Niño events, 9 La Niña events, 11 positive IOD (pIOD) events and 5 negative IOD (nIOD) events were found on the record (list of events can be seen in the appendix). There are concurrence occasions between pIOD events and El Niño events in 1994/1995, 1997/1998, 2006/2007 and 2015/2016. On the other hand, the pIOD events co-occurred with the La Niña periods in 2000/2001, 2007/2008, 2008/2009 and 2011/2012. The nIOD event coincides the El Niño event in 2014/2015 and the strong La Niña event in 1998/1999.

As the attempt to enhance the relationship between the inter-annual variability of surface geostrophic current and climate event, Fig. 10 plots the climate event with the variability of surface geostrophic current over 19932016 period. Overall, the clear composition was observed having the same pattern with seasonal variability where the upper and middle part of the Sumba strait are dominated by the eastward current going to the Savu Sea while the westward current moves to the Indian Ocean in the southern part of the Strait. It is revealed that the magnitude of the eastward current is higher than the westward one. The highest magnitude of the westward current occurred in 2009, 2001 and 2015 with the magnitude $-0.318 \mathrm{~m} / \mathrm{s},-0.288 \mathrm{~m} / \mathrm{s}$ and -0.285 $\mathrm{m} / \mathrm{s}$ respectively. Based on the previous result on the climate modes section, there were two continuously climate events in 2009 with started from La Niña 2008/2009 and El Niño 2009/2010. For the 2001 and 2015, there was La Niña event in 2000/2001 and two continuously El Niño event in 2014 until 2016. At that time the El Niño 2015/2016 was categorized as the strong El Niño event. Furthermore, there was also a strong pIOD event in 2015. On the other hand, the lowest value in surface geostrophic velocity happened in 1995,2008 and 1998 with the respect magnitude -0.16 $\mathrm{m} / \mathrm{s},-0.15 \mathrm{~m} / \mathrm{s}$ and $-0.13 \mathrm{~m} / \mathrm{s}$ happened in 1995,2008 and 1998 with the respective value $-0.16 \mathrm{~m} / \mathrm{s},-0.15 \mathrm{~m} / \mathrm{s}$ and $-0.13 \mathrm{~m} / \mathrm{s}$. Those years are followed by the strong $\mathrm{La}$ Niña 2007/2008, 2008 pIOD also two consecutive El Niño 1994/1995 and La Niña 1995/1996 event. Surprisingly, there was a big climate event in 1998 which had known as the very strong El Niño 1997/1998 and tailed by strong La Niña 1998/1999 and 1998 nIOD event.

The highest magnitude for the northern part of the strait happened in 2014, 1997, 2007 and 2003 with the value $0.385 \mathrm{~m} / \mathrm{s}, 0.384 \mathrm{~m} / \mathrm{s}, 0.358 \mathrm{~m} / \mathrm{s}$ and $0.339 \mathrm{~m} / \mathrm{s}$ correspondingly which occurred in station 3 . Among of them, only in the year 1997 and 2014, it was also accompanied by the $0.1 \mathrm{~m} / \mathrm{s}$ magnitude in the middle part (station 2). All of those years were in the pIOD except 2014 nIOD event. The 1997 pIOD co-occurred with the very strong El Niño 1997/1998 and was followed by strong La Niña 1998/1999 while 2007 pIOD overlapped with the strong La Niña 2007/2008 event. As the contrary condition, the lowest number for the velocity in station 3 occurred in 1998 nIOD event with $0.17 \mathrm{~m} / \mathrm{s}$. Interestingly, there is an unusual westward current for the station 2 in 2015 with the magnitude $0.006 \mathrm{~m} / \mathrm{s}$ when that year was marked as the strong pIOD and strong El Niño 2015/2016 event. From this result, it is difficult to state about the exact relationship between the regional climate modes and interannual variation of surface geostrophic current in the Sumba strait since there is an unclear pattern for each climate events which can influence its variability. 

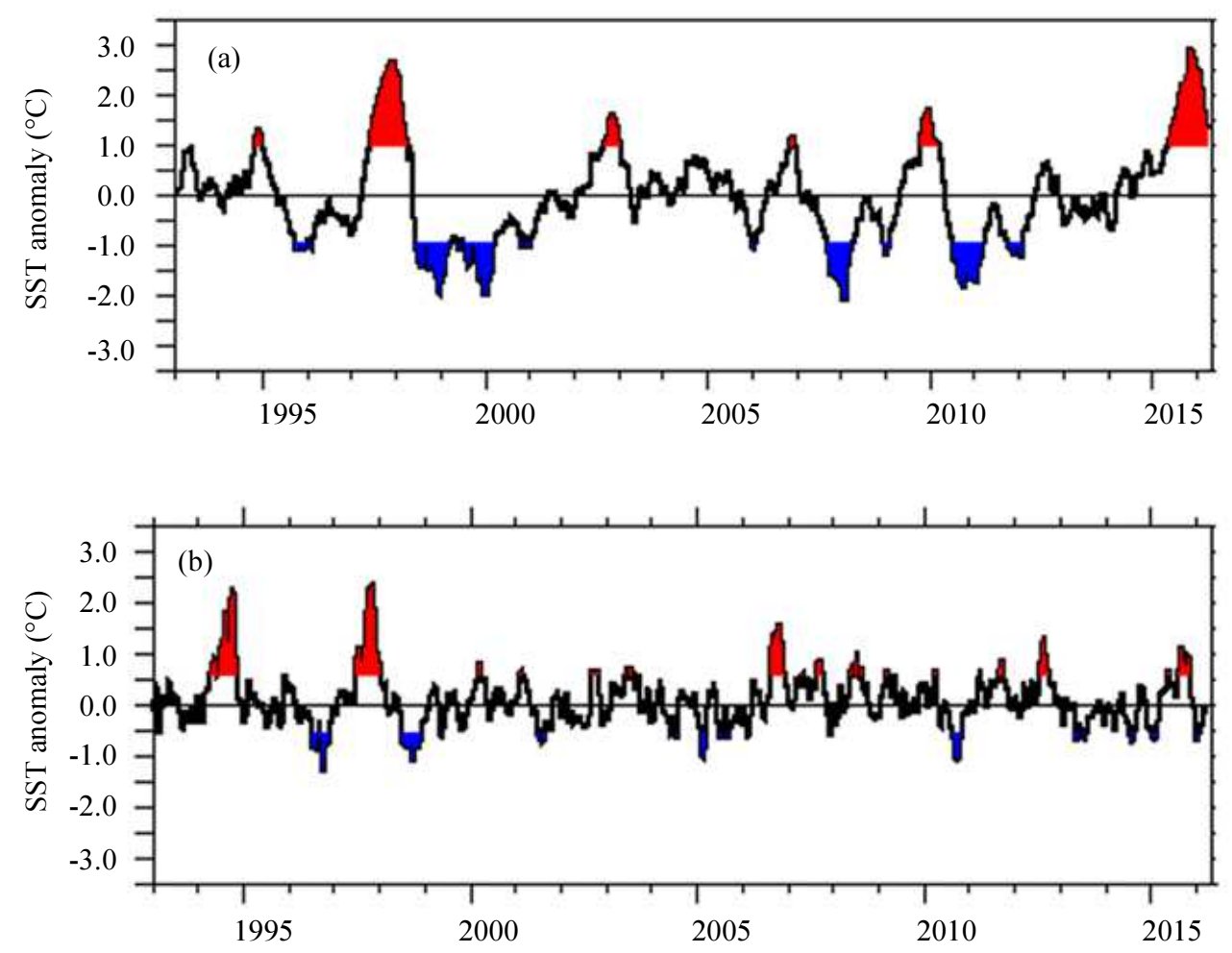

Fig. 9: Ocean-Atmosphere modes time series based on (a) NINO 3.4 index (b) Dipole Mode Index (DMI) from 1993-2016. The red shade indicates the occurance of El Niño and pIOD events while the blue shade shows the presence of La Niña and nIOD events

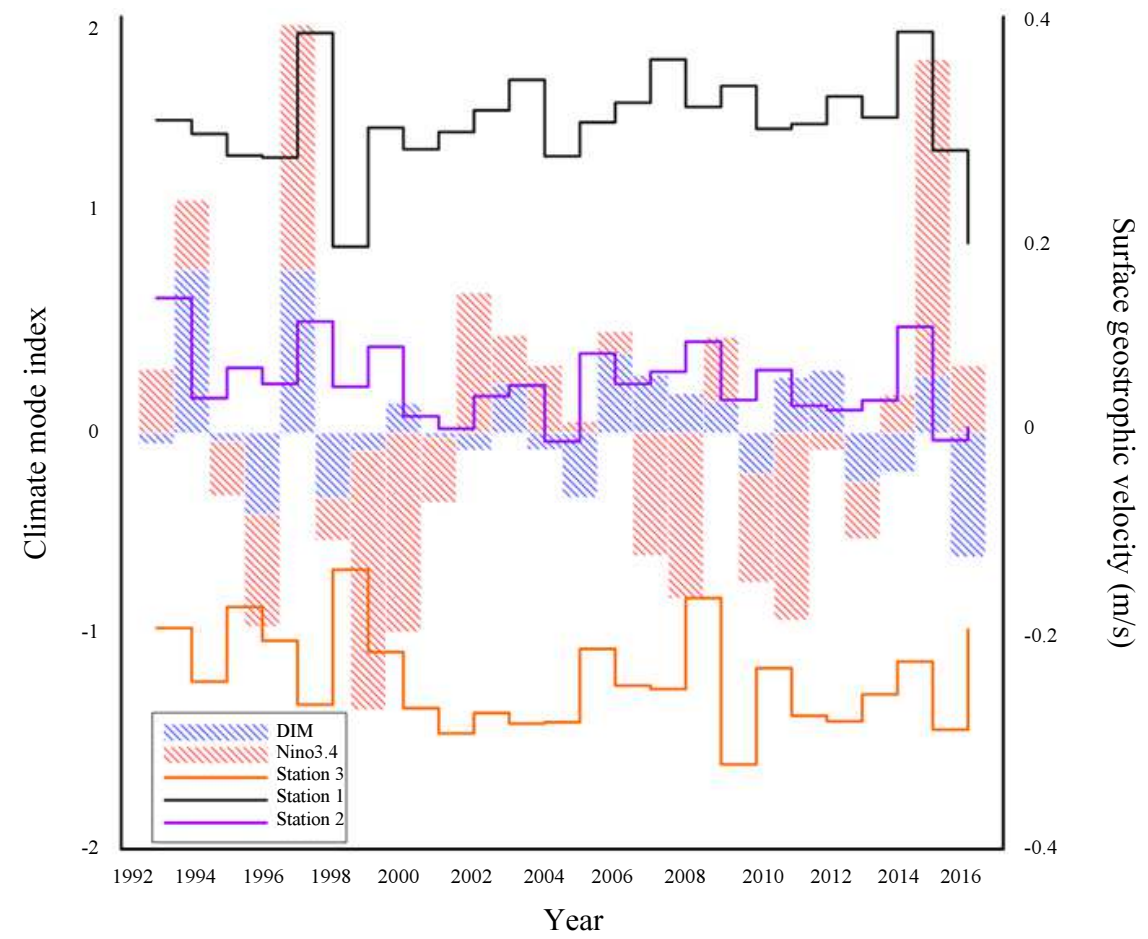

Fig. 10: Plot of the Interannual Variability of surface geostrophic velocity and climate event in Sumba Strait during 1993-2016. The minus sign of velocity refers to the westward flow and plus sign means to the east direction 
Using the statistic approach, the regression analysis is used to figure out the relationship between surface geostrophic variability and climate index. This method employed the climate index as the $\mathrm{x}$ (independent) component and the variability of surface geostrophic velocity stands for $y$ (dependent) component. However, considering the throughflow may give the impact to the climate index and providing the robustness of the result, this analysis also runs the climate index as the $y$ variable and $\mathrm{x}$ variable comes from geostrophic velocity.

Giving the plot between DMI Index as the $\mathrm{x}$ and velocity as the y component (Table 2), the result showed that there is a strong significant correlation between DMI and the velocity in the station 1 and 3 with the pvalue is lower than $1 \%$ and $5 \%$ respectively. P-value defines the significance of correlation where the lower $\mathrm{p}$-value is the stronger significant because it can be also referred as the rate of error. The interesting result occurred in the different slope value for both stations by giving 3.698 and -3.147 correspondingly. This finding means the surface geostrophic movement in the upper Sumba Strait (station 1) is strongly influenced by the Indian Ocean climate index while the dynamic of Indian Ocean does not give the linear influence on the surface geostrophic in the southern part of the strait (station 3). This condition is potentially caused by the westward ITF current in the station 3 (observation data) which flows with the main force coming from ocean-atmospheric coupling in the Pacific Ocean. In addition, based on the satellite data (previous section), this westward current appears in almost every monsoon.

Given a reverse equation with the different $x-y$ component where the climate index as the dependent variable (Table 3 ), the results illustrated that the throughflow has the strong significant correlation to the DMI in the station 1 and 3 with the p-value is less than $1 \%$ and $5 \%$ respectively. Similar to the previous finding, the different correlations appear in those stations with the positive and negative correlation which were given by the slope value 0.0784 and -0.0162 respectively.

On the other hand, the relationship between NINO 3.4 and surface geostrophic variability which is presented in Table 4 and Table 5 stated that there is no significant correlation between them. Furthermore, although there is a change in $x-y$ component to define the independent and dependent variable, the positive and negative correlation remain in the same location (positive slope value in station 1; negative slope value in Station 2 and 3) for NINO 3.4 Index- surface geostrophic connection. Shortly, based on Table 2 until Table 5, the results confirm that the climate index from the Indian Ocean has more significant correlation than the Pacific Ocean on the throughflow in the Sumba Strait. Furthermore, these findings also emphasize that the throughflow may well be impacted as well as feedback on both ENSO and IOD since there is robustness in those variables.

Related to the correlation between monthly geostrophic transport from MIMOC data and the monthly average of climate index, the findings highlight both of IOD and ENSO have the strong significant correlation to the geostrophic transport variability with p-value is less than $10 \%$ and $5 \%$ respectively (Table 6) and vice versa (Table 7). Interestingly, this result is different from the climate index-surface geostrophic relationship. The ENSO has a stronger significant relationship than IOD. However, there is no linear influence between those two variables since the minus slope value in both Table $6(-0.168$ and -0.195$)$ and Table 7 (-1.489 and -1.8) defining the negative correlation. These findings confirm that the seasonal cycle is more dominant on the throughflow variability within the Sumba Strait.

Table 2: Data analysis result between surface geostrophic (as y component) and DMI index (as x component) using regression over 24 years (1993-2016)

\begin{tabular}{llll}
\hline DMI & Model 1 & Model 2 & Model 3 \\
\hline sta1 & $\begin{array}{l}3.698^{* * *} \\
(1.234)\end{array}$ & & \\
sta2 & & 0.579 & \\
& & $(1.980)$ & \\
sta3 & & & $-3.147^{* *}$ \\
& & & $(1.373)$ \\
Constant & $-1.049^{* * *}$ & 0.021 & $-0.694^{* *}$ \\
& $(0.371)$ & $(0.118)$ & $(0.331)$ \\
Observations & 24 & 24 & 24 \\
R-squared & 0.290 & 0.004 & 0.193 \\
\hline Standard
\end{tabular}

Standard errors in parentheses

${ }^{* * *} \mathrm{p}<0.01,{ }^{* *} \mathrm{p}<0.05,{ }^{*} \mathrm{p}<0.1$

Table 3: Data analysis result between surface geostrophic (as $x$ component) and DMI index (as y component) using regression over 24 years (1993-2016)

\begin{tabular}{llll}
\hline & $(1)$ & $(2)$ & $(3)$ \\
& Sta1 & Sta2 & Sta3 \\
\hline DMI & $0.078^{* * *}$ & 0.006 & $-0.061^{* *}$ \\
& $(0.026)$ & $(0.022)$ & $(0.026)$ \\
Constant & $0.293^{* * *}$ & $0.0472^{* * *}$ & $-0.233^{* * *}$ \\
& $(0.008)$ & $(0.007)$ & $(0.008)$ \\
Observations & 24 & 24 & 24 \\
R-squared & 0.290 & 0.004 & 0.193 \\
\hline
\end{tabular}

Standard errors in parentheses

$* * * \mathrm{p}<0.01, * * \mathrm{p}<0.05, * \mathrm{p}<0.1$ 
Table 4: Data analysis result between surface geostrophic (as y component) and NINO 3.4 (as $x$ component) using regression over 24 years (1993-2016)

\begin{tabular}{llll}
\hline NINO3.4 & Model 1 & Model 2 & Model 3 \\
\hline sta1 & 1.668 & & \\
sta2 & $(2.816)$ & & \\
& & -1.598 & \\
sta3 & & $(3.832)$ & -4.141 \\
& & & $(2.828)$ \\
Constant & -0.543 & 0.0291 & -1.025 \\
& $(0.847)$ & $(0.227)$ & $(0.681)$ \\
Observations & 24 & 24 & 24 \\
R-squared & 0.016 & 0.008 & 0.089 \\
\hline
\end{tabular}

Table 5: Data analysis result between surface geostrophic (as $x$ component) and NINO 3.4 (as y component) using regression over 24 years (1993-2016)

\begin{tabular}{llll}
\hline & $(1)$ & $(2)$ & $(3)$ \\
& Sta1 & Sta2 & Sta3 \\
\hline NINO3.4 & 0.009 & -0.004 & -0.021 \\
& $(0.015)$ & $(0.011)$ & $(0.014)$ \\
Constant & $0.297^{* * *}$ & $0.0473^{* * *}$ & $-0.237^{* * *}$ \\
& $(0.010)$ & $(0.007)$ & $(0.009)$ \\
Observations & 24 & 24 & 24 \\
R-squared & 0.016 & 0.008 & 0.089 \\
\hline
\end{tabular}

Standard errors in parentheses

$* * * \mathrm{p}<0.01,{ }^{* *} \mathrm{p}<0.05,{ }^{*} \mathrm{p}<0.1$

Table 6: Data analysis result between geostrophic transport (as $\mathrm{y}$ component) and climate index (as $\mathrm{x}$ component) using regression over 24 years (1993-2016)

\begin{tabular}{llll}
\hline & $(1)$ & $(2)$ \\
& Transport & Transport \\
\hline DMI & $-0.168^{*}$ & \\
NINO3.4 & $(0.092)$ & $-0.195^{* *}$ \\
& & $(0.083)$ & \\
Constant & $-0.043^{* * *}$ & $-0.061^{* * *}$ & \\
& $(0.009)$ & $(0.008)$ & \\
Observations & 12 & 12 & 0.351 \\
R-squared & & 0.250 & \\
\hline
\end{tabular}

Table 7: Data analysis result between geostrophic transport (as $\mathrm{x}$ component) and climate index (as y component) using regression over 24 years (1993-2016)

\begin{tabular}{lll}
\hline & $(1)$ & $(2)$ \\
& DMI & NINO3.4 \\
\hline Transport & $-1.489^{*}$ & $-1.800^{* *}$ \\
& $(0.815)$ & $(0.774)$ \\
Constant & -0.028 & $-0.141^{* *}$ \\
& $(0.048)$ & $(0.046)$ \\
Observations & 12 & 12 \\
R-squared & 0.250 & 0.351 \\
\hline
\end{tabular}

Standard errors in parentheses

$* * * \mathrm{p}<0.01,{ }^{* *} \mathrm{p}<0.05,{ }^{*} \mathrm{p}<0.1$

\section{Discussion}

Sumba Strait is situated in the southern part of the Lesser Sunda Islands acting as the direct border between the internal Indonesian seas and the Indian Ocean. It marks the promising place for the meeting point between the Pacific water mass which is transported as ITF from the inflow gates of northern Indonesian region and Indian Ocean water mass associated with the SJC. Those factors can give the influence on the variability for the ocean water movement flowing in the Sumba Strait. This study has presented the result from observation measurement containing the water properties such as temperature and salinity profile that gives the evidence of water mass source. Furthermore, the information of geostrophic velocity and snapshot transport based on hydrographic stations which are referenced by measuredcurrent from vessel-mounted ADCP also has provided in the previous section. In order to enhance the understanding on the variability of the flows in the Sumba Strait, the long-time series data from the satellite altimetry data during 1993-2016 and monthly climatology of hydrography data from MIMOC were used to characterize the seasonal and inter-annual variations both for surface geostrophic velocity and geostrophic transport.

The seasonal variability of surface geostrophic velocity which was observed in this study indicates the eastward current dominating the northern part of Strait while the small portion in the southern section is governed by the westward flow. Supported by the temperature and salinity profile, this study believes that there is an intrusion of Pacific and Indian Ocean water mass in the upper layer (0-600 m) of Sumba Strait so the eastward and westward current in this area can be interpreted as the SJC which acts as coastal Kelvin wave from the equatorial Indian Ocean and ITF as the water mass resource from the Pacific Ocean respectively. This interpretation is supported by the previous study which stated that an observed South Java Current flows to the Banda Sea via Sumba Strait as well as Ombai Strait (Hautala et al., 2001; Sprintall et al., 2010). In addition, the result of temperature value in this study is relatively low. This condition is suggested as the influence of potential extended propagation of SJC since it brings the cool water and decreases the sea surface temperature in Sumba Strait (Bayhaqi et al., 2018).

The findings highlight the reverse flow of SJC which started to move to east direction at the beginning of the first transitional monsoon period (March) from the north-westward current in the northwest monsoon. This eastward current of SJC is earlier than Sprintall et al. (1999) who found the eastward SJC from the early May based on the mooring data. The SJC remains to the east direction until the late second transitional monsoon season (November). These results are totally different to the north-westward flow estimated in the southeast monsoon (KNMI, 1949). However, the outcomes are also consistent with the strong eastward subsurface current of SJC during the southeast monsoon (Hautala et al., 2001; 
Sprintall et al., 2010). During August-October, the eastward SJC will bring the saline water and trigger a wind-driven upwelling of NIIW then the evaporation increases in this season (Wyrtki, 1961).

Related to the westward ITF, it was detected that the surface velocity during the northwest monsoon is higher than the southeast monsoon. Consistent with Sprintall et al. (2010), the SJC current will move stronger during southeast monsoon at the surface layer in the northern part of Ombai Strait through the Savu Sea. This SJC movement may strongly penetrate the ITF westward current in the Sumba Strait and reduce the velocity during this monsoon period. This condition is completely opposite to the other outflow straits such as Ombai Strait, Lombok Strait and Timor passage where the maximum flow occurs during the southeast monsoon (Sprintall et al., 2009). Thus, the result also emphasizes that only a small part of ITF in the surface layer which turns to the Indian Ocean via Sumba Strait when the strong transport flows in the dry season. Furthermore, the total geostrophic transport along $700 \mathrm{~m}$ depth showed the clear figure that the maximum transport of ITF occurs during the southeast monsoon. However, although the dominant direction for the transport in the Sumba Strait moves westward toward the Indian Ocean, the value of transport is less than $0.1 \mathrm{SV}$. This number is very small compared to Chong et al. (2000) in the study of throughflow variability in the Sumba Strait and other main outflow straits of the ITF. This condition is potentially due to the different handlings in the transport calculation where he stated the total transport from ADCP in the $100 \mathrm{~m}$ surface. Based on these findings, the proposed illustration of ITF route adapted from Sprintall et al. (2009) can be seen in Fig 11.

On the inter-annual variation, the throughflow involves the climate modes in the two basins, the Pacific and Indian Oceans. The inter-annual variability showed the unclear pattern to state which the climate modes most affect the variability in the Sumba Strait. The ITF propagation is influenced by the Pacific Ocean dynamic since the fluctuation of Pacific trade winds can give a different impact to the pressure gradient in the west side Pacific. This Pacific dynamic can strongly affect the output of ITF (Gordon et al., 2012; Sprintall et al., 2014). La Niña condition occurs when the strong trade winds weaken the westerly winds in the tropical Pacific and trigger the high intensity of ITF transport (Meyers, 1996; Gordon and McClean, 1999). However, the findings of this study reveal the contrast condition when one of the highest westward surface geostrophic currents occurred in the strong 2015/2016 El Niño event. Furthermore, the lowest velocity happened in the strong 1998/1999 La Niña event. Similar condition with the seasonal variability, these outcomes confirm that the strong intensity of ITF transport during La Niña period does not have much effect to the variability in Sumba since most of the flow moves to the south and exit to the Indian Ocean via Savu/Dao Strait and Timor passage. On the opposite condition, the eastward SJC associated with the Kelvin wave will be influenced by the Indian Ocean dynamic. The high velocity of eastward surface geostrophic occurs in the pIOD years while the low magnitude was accompanied by the strong nIOD in 1998 .

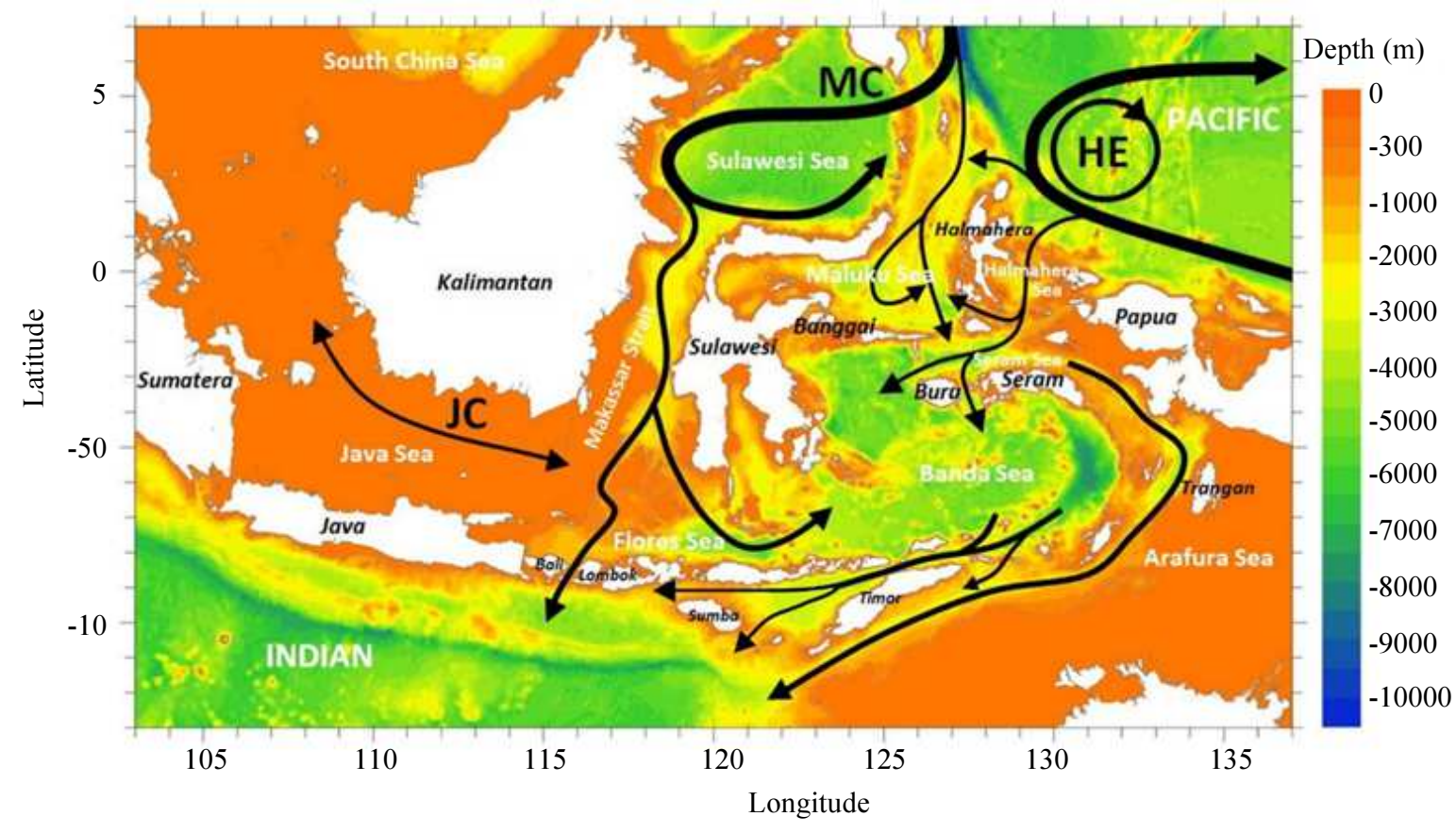

Fig. 11:The schematic of ITF route adapted from Sprintall et al. (2009) with the extended propagation of westward ITF component from Ombai into Sumba Strait based on geostrophic calculation 
This study also highlights the different response between surface geostrophic and geostrophic transport to climate mode. Based on the linear correlation result from the previous section, the surface geostrophic has a high correlation with the Indian Ocean dynamic. This result is possibly caused by the influence of zonal wind in the equatorial Indian Ocean. In addition, Liu et al. (2015) found that IOD can give more penetration to the ITF through the local wind of Sumatra-Java which also induces the coastal Kelvin wave. Thus, the equatorial Indian Ocean wind dynamic can be an equaliser to the ENSO-ITF variability connection. However, looking at the correlation between geostrophic transports to the climate condition, the Pacific Ocean dynamic through the ENSO phenomenon surpass the correlation value of DMI-geostrophic transport. This result is consistent with the previous study which mentioned that ITF transport variability is likely influenced by the Pacific climate variability (Han et al., 2010). Furthermore, in the past decades, global warming may increase the heat transport from the Pacific into the Indian Ocean (Lee et al., 2015) and a sequence of La Niñaevent in the last 2000s can trigger the enhancement of that heat movement (Liu et al., 2015).

This paper emphasizes the trace of two water masses from Indian and Pacific in Sumba Strait as well as its variability. However, the specific study about the signal of SJC variability within Sumba Strait is highly needed. In addition, this research also opens a potential future topic on how well those water masses do mixing and its relationship on the marine ecosystem.

\section{Conclusion}

In conclusion, Sumba Strait provides the small portion of westward ITF before exiting to the Indian Ocean. The variability of geostrophic current in Sumba Strait showed the dominant seasonal pattern. While the westward geostrophic current velocity as the extent of ITF from the Ombai Strait has the high intensity during the northwest monsoon in the surface layer, the variability of total geostrophic transport in $700 \mathrm{~m}$ depth expressed that the value of westward transport is less than $0.1 \mathrm{~Sv}$ and the maximum transport occurs during southeast monsoon. The intrusion of eastward surface geostrophic current confirms that the strong reversal eastward SJC flow occurs in the southeast monsoon (JJA - June, July and August) which started in the first transitional period and remains going to the east until the end of second transitional period (SON - September, October and November). Although there is an unclear pattern between climate index and geostrophic variability in the inter-annual variation, the findings emphasize that the Indian Ocean climate mode give more influence to the inter-annual variability in the surface layer within Sumba strait. On the other hand, the dynamic of Pacific Ocean holds an important role in influencing the geostrophic transport fluctuation flowing in the Sumba Strait.

\section{Acknowledgement}

The authors would like to express the thanks of gratitude to the Research Center for Oceanography (RCO) - Indonesian Institute of Sciences (LIPI), who provided the observation data from the annual research cruise, Ekspedisi WIdya Nusantara (EWIN) 2016. Then the special thanks are also sent to the Chevening Scholarship, the UK government's global scholarship programme, funded by the Foreign and Commonwealth Office (FCO) and partner organisations who give the chance for the first author to do a research collaboration through a degree scholarship scheme.

\section{Author's Contributions}

Ahmad Bayhaqi: Contributed to research design, acquisition data, intellectual content, drafting and writing the paper.

Yueng-Djern Lenn: Contributed to research design, intellectual content reviewing the article.

Dewi Surinati: Contributed to field work, acquisition data, writing paper.

Jeff Polton: Contributed to research design, providing model data, reviewing the article.

Muhamad Nur: Contributed to processing and interpretation of climate data, intellectual content.

Corry Corvianawatie: Contributed to processing and interpretation of observational data, intellectual content.

Adi Purwandana: Contributed to processing and interpretation of observational data, intellectual content.

\section{Ethics}

This article contains an original idea and an unpublished study. The authors have read and confirmed that there are no ethical issues involved in this manuscript.

\section{References}

Arief, D. and S. Murray, 1996. Low frequency fluctuations in the indonesian throughflow through lombok strait. J. Geophys. Res., 101: 12.455-12.464.

Atmadipoera, A., R. Molcard, G. Madec, S. Wijffels and J. Sprintall et al., 2009. Characteristics and variability of the indonesian throughflow water at the outflow straits. Deep Sea Res. I, 56: 1942-1954.

Bayhaqi, A., I. Iskandar, D. Surinati, A.S. Budiman and A.K. Wardhana et al., 2018. Water mass characteristic in the outflow region of the indonesian throughflow during and post 2016 negative indian ocean dipole event. IOP Conf. Series: Earth Environ. Sci.

Broecker, W.S., 1997. Thermohaline circulations, the achilles heel of our climate system: will man made $\mathrm{CO} 2$ upset the curent balance? Science, 287: 1582-1588. 
Chong, J.C., J. Sprintall, S. Hautala, W.L. Morawitz and N.A. Bray et al., 2000. Shallow throughflow variability in the outflow straits of indonesia. Geophys. Res. Lett., 27: 125-128.

Clarke, A.J. and X. Liu, 1993. Observations and dynamics of semi-annual and annual sea levels near the eastern equatorial indian ocean boundary. J. Phys. Oceanogr., 23: 386-399.

England, M.H. and F. Huang, 2005. On the interannual variability of the Indonesian throughflow and its linkage with ENSO. J. Climate, 18: 1435-1444.

Fan, W., Z. Jian, Z. Chu, H. Dang and Y. Wang et al., 2018. Variability of the indonesian throughflow in the makassar strait over the last $30 \mathrm{ka}$. Nat. Sci. Report, 8: 5678-5678.

Feng, M., N. Zhang, Q. Liu and S. Wijffels, 2018. The Indonesian thoughflow, its variability and centennial change. Geosci. Lett.

Ganachaud, A., C. Wunsch, J. Marotzke and J. Toole, 2000. Meridional overturning and large- scale circulation of the Indian Ocean. J. Geophys. Res., 105: 26117-26134.

Godfrey, J.S., 1996. The effect of the indonesian throughflow on ocean circulation and heat exchange with the atmosphere: A Review. J. Geophys. Res., 101: 12,217-12,237.

Gordon, A.L. and J.L. McClean, 1999. Thermohaline stratification of the indonesian seas: Model and observations*. J. Phys. Oceanography, 29: 198-216.

Gordon, A.L., 1986. Interocean exchange of thermocline water. J. Geophys. Res., 91: 5037-5037.

Gordon, A.L., B.A. Huber, E.J. Metzger, R.D. Susanto and H.E. Hurlburt et al., 2012. South China Sea throughflow impact on the Indonesian throughflow. Geophys. Res. Lett., 39: 1-7.

Gordon, A.L., J. Sprintall, H.M. Van Aken, R.D. Susanto and S. Wijffels et al., 2010. The Indonesian throughflow during 2004-2006 as observed by the INSTANT program. Dynamics Atmospheres Oceans, 50: 115-128.

Gordon, A.L., R.D. Susanto, A. Ffield, B.A. Huber and W. Pranowo et al., 2008. Makassar strait throughflow, 2004 to 2006. Geophy. Res. Lett., 35: 3-7.

Han, W., G.A. Meehl, B. Rajagopalan, J.T. Fasullo and A. $\mathrm{Hu}$ et al., 2010. Patterns of Indian Ocean Sea-level change in a warming climate. Nat. Geosci., 3: 546-550.

Hautala, S.L., J. Sprintall, J.T. Potemra, J.C. Chong and W. Pandoe et al., 2001. Velocity structure and transport of the Indonesian throughflow in the major straits restricting flow into the Indian Ocean. J. Geophys. Res., 106: 19527-19527.

Kessler, W.S., 2006. The circulation of the eastern tropical Pacific: A review. Progress Ocanography, 69: 181-217.

KNMI, 1949. Indian Ocean, seas around Australia. Oceanogr Meteorol. Data, 124: 24-24.
Koch-Larrouy, A., G. Madec, P. Bouruet-Aubertot, T. Gerkema and L. Bessières et al., 2007. On the transformation of pacific water into indonesian throughflow water by internal tidal mixing. Geophys. Res. Lett.

Lavin, M.F.E., J. Beier, V.M. Gomez-Valdes and J. Garcia, 2006. On the summer poleward coastal current off SW mexico. Geophys. Res. Lett, 33: L02601- L02601.

Lee, S.K., W. Park, M.O. Baringer, A.L. Gordon and B. Huber et al., 2015. Pacific origin of the abrupt increase in indian ocean heat content during the warming hiatus. Nat. Geosci., 8: 445-449.

Liu, Q.Y., M. Feng, D. Wang and S. Wijffels, 2015. Interannual variability of the indonesian throughflow transport: A revisit based on 30-year expendable bathythermograph data. J. Geophys. Res. Oceans, 120: 8270-8282.

Meyers, G., 1996. Variation of indonesian throughflow and the El Niño southern oscillation. J. Geophys. Res, 101: 12,255-12,263.

Meyers, G., R.J. Bailey and A.P. Worby, 1995. Geostrophic transport of indonesian throughflow. Deep Sea Res. Part 1, 42: 1163-1174.

Pond, S. and G.L. Pickard, 1983. Introductory Dynamic Oceanography. 2nd Edn., Elsevier.

Pond, S. and G.L. Pickard, 1978. Introductory Dynamic Oceanography. 1st Edn., Pergamon Press.

Quadfasel, D. and Creswell, G.R. 1992. A note on the seasonal variability of the South Java Current. J. Geophys. Res., 97: 3685-3688.

Saji, N.H., B.N. Goswani, P.N. Vinayachandran and T. Yamagata, 1999. A dipole mode in the tropical Indian Ocean. Nature, 401: 360-363.

Schneider, N., 1998. The Indonesia throughflow and the global climate system. J. Climate, 11: 676-689.

Shinoda, T., W. Han, E.J. Metzger and H.E. Hurlburt, 2012. Seasonal variation of the indonesian throughflow in makassar strait. J. Phys. Oceanography, 42: 1099-1123.

Sprintall, J. and A. Revelard, 2014. The Indonesian throughflow response to indo-pacific climate variability. J. Geophys. Res. Oceans, 119: 1161-1175.

Sprintall, J., A.L. Gordon, A. Koch-Larroy, T. Lee and J.T. Potemra et al., 2014. The indonesian Seas and their role in the Coupled Ocean-Climate system. Nat. Geosci., 7: 487-492.

Sprintall, J., A.L. Gordon, R. Murtugude and R.D. Susanto, 2000. A semiannual Indian Ocean forced kelvin wave observed in the Indonesian seas in May 1997. J. Geophys. Res., 105: 17,217-17,230.

Sprintall, J., J. Chong, F. Syamsudin, W. Morawitz and S. Hautala et al., 1999. Dynamics of the South Java Current in the Indo-Australian Basin. Geophys. Res. Lett., 26: 2493-2496. 
Sprintall, J., J.T. Potemra, S.L. Hautala, N.A. Bray and W.W. Pandoe, 2003. Temperature and salinity variability in the exit passages of the indonesian throughflow. Deep-Sea Res. Part II: Topical Stud. Oceanography, 50: 2183-2204.

Sprintall, J., S. Wijffels, R. Molcard and I. Jaya, 2010. Direct evidence of the South Java Current system in Ombai Strait. Dynamics Atmospheres Oceans, 50: 140-156.

Sprintall, J., S.E. Wijffels, R. Molcard and I. Jaya, 2009. Direct estimates of the Indonesian throughflow entering the Indian Ocean: 2004-2006. J. Geophys. Res. Oceans, 114: C07001- C07001.

Stewart, R.H., 2002. Introduction to Physical Oceanography. Texas A and M University.

Strub, P.T. and C. James, 2002. Altimeter-derived surface circulation in the large-scale NE Pacific gyres: Part 1, seasonal variability. Prog. Oceanogr, 53. 163-183.

Susanto, R., A. Ffield, A.L. Gordon and T.R. Adi, 2012. Variability of Indonesian throughflow within Makassar Strait, 2004-2009. J. Geophys. Res. Oceans, 117: C09013- C09013.

Susanto, R.D. and Y.T. Song, 2015. Indonesian throughflow proxy from satellite altimeters and gravimeters. J. Geophys. Res. Oceans, 120: 2844-2855.
Syamsudin, F., A. Kaneko and D.B. Haidvogel, 2004. Numerical and observational estimates of Indian Ocean Kelvin wave intrusion into lombok strait. Geophys. Res. Lett., 31: L24307- L24307.

Talley, L.D., G.L. Pickard, W.J. Emery and J.H. Swift, 2011. Descriptive Physical Oceanography: An Introduction. 1st Edn., Elsevier Science \& Technology.

Trenberth, K.E., J.M. Caron, D.P. Stepaniak and S. Worley, 2002. The evolution of ENSO and global atmospheric surface temperatures. J. Geophys. Res., 107. 4065-4065.

Vranes, K., A.L. Gordon and A. Ffield, 2002. The heat transport of the Indonesian throughflow and implications for the Indian Ocean heat budget. Deep-Sea Res. Part II: Topical Studies Oceanography, 49: 1391-1410.

Wijffels, S., R.W. Schmidt, H.L. Bryden and A. Stigebrandt, 1992. Transport of freshwater by the oceans. J. Phys. Oceanogr, 22: 156-162.

Wyrtki, K., 1973. An equatorial jet in the Indian Ocean. Science, 181; 262-264

Wyrtki, K., 1961. Physical oceanography of the Southeast Asian waters. NAGA report.

Wyrtki, K., 1987. Indonesian through flow and the associated pressure gradient. J. Geophys. Res., 92: 12941-12941. 